fluxes may provide important insight into the mechanism of hypertension.

We thank the British Heart Foundation for supporting this project.

\section{References}

1 Swales JD. Ion transport in hypertension. Biosci Rep 1982;2:967-90.

2 Edmondson RPS, Thomas RD, Hilton PJ, Patrick J, Jones NF. Abnormal leucocyte composition and sodium transport in essential hypertension. Lancet 1975; ; 1003-5.

3 Heagerty AM, Bing RF, Thurston H, Swales JD. Calcium antagonists in hypertension: relation to heagerty AM, Bing RF, Thurston H, Swales JD. Calcium a
abnormal sodium transport. Br.Med F 1983;287:1405-7.

4 Postnov YV, Orlov SN, Pokudin NI. Decrease of calcium binding by the red blood cell membrane

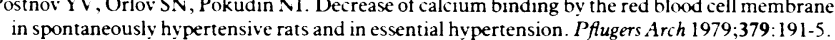
in spontaneously hypertensive rats and in essential hypertension. Pflugers Arch 1979;379:191-5.
Wei JW' Janis RA. Daniel EE. Calcium accumulation and enzymatic activities of subcellular ei JW, Janis RA, Daniel EE. Calcium accumulation and enzymatic activities of subcellular
fractions from aortas and ventricles of genetically hypertensive rats. Circ Res 1976;39:133-40. fractions from aortas and ventricles of genetically hypertensive rats. Circ Res 1976;39:133-40.
Heagerty AM, Milner M, Bing RF, Thurston H, Swales JD. Leucocyte membrane sodium transport in normotensive populations: dissociation of abnormalities of sodium efflux from raised blood pressure. Lancet 1982;ii:894-6.

7 Woods JW, Falk RJ, Pittman AW', Klemmer PJ, Watson BS, Namboodiri K. Increased red cell sodium-lithium countertransport in normotensive sons of hypertensive parents. N Engl f Med 1982;306:593-5

8 Mever P, Garay RP, Nazaret C, et al. Inheritance of abnormal erythrocyte cation transport in essential hypertension. Br.Med 7 1981;282:1114-7.

9 Heagerty AM, Riozzi A, Brand SC. Bing RF. Thurston H. Swales JD. Membrane transport of ions in hypertension: a review. Acta Med Scand 1985;46 suppl 180:54-64.

10 Postnov YV, Orlov SN. Cell membrane alteration as a source of primary hypertension. fournal of Hypertension 1984:2:1-6.

11 Montenav-Garestier T, Aragon I, Devynck K, Meyer P, Helene C. Evidence for structural changes in erythrocyte membranes of spontaneously hypertensive rats. A fluorescence changes in erythrocyte membranes of spontaneously hyperten

12 Reznikova MB, Adler AM, Postnov YV. Erythrocyte membrane sialic acids in primary and secondary hypertension in man and rat. Eur $\mathcal{F}$ Clin Incest 1984;14:87-9.
13 Wood DA. Butler S. Riemersma RA, et al. Adipose tissue and platelet fatty acids and coronary heart disease in Scottish men. Lancet 1984;ii: 117-22.

14 Kishimoto A, Takai Y, Mori T, Kikkawa U, Nishizuka Y. Activation of calcium and phospholipid-dependent protein kinase by diacylglycerol; its possible relation to
phention phospholipid-dependent protein kinase by diacylglycerol; its possible relation to
phosphatidylinositol turnover. $f$ Biol Chem 1980;255:2273-6.

15 Jorgensen PL. Isolation and characterization of the components of the sodium pump. $Q R e c$ Biophys 1975;7:239-74

16 Rouse JL, Beilin LJ. Vegetarian diet and blood pressure. Fournal of Hypertension 1984:2:231-40.

17 Sanders TAB, Ellis FR, Dickerson JW'T. Studies of vegans: the fatty acid composition of plasma choline phosphoglycerides, erythrocytes, adipose tissue and breast milk, and some indicators of susceptibility to ischemic heart disease in vegans and omnivore controls. Am J Clin Nutr 1978;31:805-13.

18 Puska P, Iacono JM, Nissinen A, et al. Controlled, randomized trial of the effect of dietary fat on blood pressure. Lancet 1983:i:1-5.

19 Milner M, Heagerty AM, Bing RF, Thurston H, Swales JD. Changes in leucocyte sodium transport in normotensive relatives of hypertensive subjects: dissociation from blood pressure. transport in normotensive re

20 Hilton PJ, Patrick J. Sodium and potassium flux rates in normal human leucocytes in an artificial extracellular fluid. Clin Sci 1973:44:439-45.

21 Rose $\mathrm{HG}$, Ocklander $\mathrm{M}$. Improved method for the extraction of lipids from human erythrocites. 7 Lipid Res 1965;6:428-31.

22 Kernoff BA, Willis AL, Stone KJ, Davies JA, McNicol GP. Antithrombotic porential of dihommo-gamma-linoleic acid. Br.Med $\mathcal{J}$ 1977; ii:1441-4

23 Margetts BM, Beilin JL, Armstrong BK, et al. Blood pressure and dietary polyunsaturated and saturated fats: a controlled trial. Clin Sci 1985; 69:165-75

24 Rouse IL, Beilin LJ, Armstrong BK, Vandongen R. Blood pressure lowering effect of a vegetarian diet: controlled trial in normotensive subjects. Lancet 1983;i:5-10.

25 Lorenz R, Spengler U, Fischer S, Duhm J, Weber PC. Platelet function, thromboxane formation and blood pressure control during supplementation of the Western diet with cod liver oil. Circulation 1983:67:504-11.

26 Roelofsen B. The non specificity in the lipid-requirement of calcium-and sodium plus potassium - transporting adenosine triphosphatases. Life $S_{c i}$ 1981;29:2335-47.

27 Tokumura A, Mostafa $\mathrm{MH}$, Nelson DR, Hanahan DJ. Stimulation of $\mathrm{Ca}^{2} \cdot \mathrm{Mg}^{2} \cdot$-ATPase activity in human erythrocyte membranes by synthetic lysophosphatidic acids and lysophatidylcholines. Effects of chain length and degree of unsaturation of the fattv acid groups. Biochem Biophys Acta 1985;812:568-74.

Accepted 23 May 1986

\title{
Increased incidence of menstrual abnormalities and hysterectomy preceding primary biliary cirrhosis
}

\author{
A J STELLON, ROGER WILLIAMS
}

\begin{abstract}
A study was performed to assess the incidence of previous hysterectomy and dilatation and curettage among women with primary biliary cirrhosis. In 87 patients with primary biliary cirrhosis hysterectomy or dilatation and curettage had been performed significantly more often than among 100 age matched normal controls and 80 age matched patients with chronic active hepatitis or alcoholic liver disease. Among the 47 patients with primary biliary cirrhosis who had undergone hysterectomy or dilatation and curettage operations had been performed at a mean of 10.7 years and 13.2 years, respectively, before the onset of disease. The main indication for hysterectomy among patients with primary biliary cirrhosis and controls was menorrhagia.

These menstrual disorders may be a consequence of high concentrations of oestrogens in patients with primary biliary cirrhosis.
\end{abstract}

\section{Introduction}

Both menorrhagia and amenorrhoea have been reported in association with chronic liver disease but not in women with primary biliary cirrhosis. In a study of patients with primary biliary cirrhosis we found an unexpectedly high proportion with menorrhagia, which had resulted in hysterectomy before the apparent onset of liver disease.

\section{Patients and methods}

Eighty seven consecutive patients with primary biliary cirrhosis, confirmed at biopsy, who were attending the outpatient department or being admitted for assessment were interviewed from January to December 1984. Patients' ages were in the range 35-70 years. A gynaecological and obstetric history was obtained from each patient, and when the patient had undergone anv gynaecological procedure the appropriate hospital was contacted and the operative and pathological findings obtained. The control groups, who were similarly interviewed, consisted of 100 age matched, healthy hospital staff and 80 age matched women with either chronic active hepatitis ( 45 patients) or alcoholic liver disease (35).

\section{Results}

The table shows that there was a striking difference between the patients with primary biliary cirrhosis and the control groups with respect to the proportion who had undergone hysterectomy. Furthermore, among patients with primary biliary cirrhosis hysterectomy had been performed a mean of $10 \cdot 7$ years (range 1-30 years) before the diagnosis of liver disease in 
Findings in patients with primary biliary cirrhosis compared with normal control subjects and patients with other liver diseases

\begin{tabular}{|c|c|c|c|c|c|c|c|c|}
\hline & $\begin{array}{l}\text { Normal controls } \\
\quad(n=100)\end{array}$ & & $\begin{array}{c}\text { Primary biliary } \\
\text { cirrhosis } \\
(\mathrm{n}=87)\end{array}$ & & $\begin{array}{c}\text { Chronic active } \\
\text { hepatitis } \\
(n=45)\end{array}$ & & $\begin{array}{l}\text { Alcoholic liver } \\
\text { disease } \\
(n=35)\end{array}$ & \\
\hline & Mean $(\mathrm{SD})$ & & $\operatorname{Mean}(\mathrm{SD})$ & & $\operatorname{Mean}(\mathrm{SD})$ & & Mean $(\mathrm{SD})$ & \\
\hline $\begin{array}{l}\text { Age (years) } \\
\text { Age at menopause } \\
\text { Age at hysterectomy (years) }\end{array}$ & $\begin{array}{l}53 \cdot 8(9 \cdot 6) \\
50 \cdot 6(2 \cdot 9) \\
42 \cdot 3(8 \cdot 2)\end{array}$ & & $\begin{array}{l}56 \cdot 1(9 \cdot 3) \\
47 \cdot 0(5 \cdot 7)^{\star} \\
42 \cdot 4(4 \cdot 8)\end{array}$ & & $\begin{array}{l}56 \cdot 2(9 \cdot 5) \\
50 \cdot 9(3 \cdot 1) \\
39 \cdot 8(4 \cdot 7)\end{array}$ & & $\begin{array}{l}54 \cdot 9(8 \cdot 6) \\
46 \cdot 8(4 \cdot 1)^{\star} \\
44(6 \cdot 1)\end{array}$ & \\
\hline $\begin{array}{l}\text { No (\%) of patients } \\
\text { No of patients with menorrhagia } \\
\text { Postmenopausal and intermenstrual bleeding } \\
\text { Dysmenorrhoea } \\
\text { Abdominal mass } \\
\text { Infertility }\end{array}$ & $\begin{array}{l}\text { Hysterectomy } \\
16(16) \\
11 \\
3 \\
1 \\
1 \\
0\end{array}$ & $\begin{array}{l}D \text { and } C \\
15(15) \\
8 \\
6 \\
1 \\
0 \\
0\end{array}$ & $\begin{array}{l}\text { Hysterectomy } \\
29(33) t \\
24 \\
2 \\
1 \\
2 \\
0\end{array}$ & $\begin{array}{l}D \text { and } C \\
26(31) \ddagger \\
17 \\
5 \\
2 \\
0 \\
2\end{array}$ & $\begin{array}{l}\text { Hysterectomy } \\
5(11) \\
3 \\
0 \\
1 \\
1 \\
0\end{array}$ & $\begin{array}{l}D \text { and } C \\
4(9) \\
1 \\
2 \\
0 \\
0 \\
1\end{array}$ & $\begin{array}{l}\text { Hysterectomy } \\
3(9) \\
2 \\
1 \\
0 \\
0 \\
0\end{array}$ & $\begin{array}{l}D \text { and } C \\
3(9) \\
1 \\
1 \\
0 \\
0 \\
1\end{array}$ \\
\hline
\end{tabular}

${ }^{\star} \mathrm{p}<0.05$ compared with normal controls (two tailed unpaired Student's $t$ test).

$t \mathrm{p}<0.025$ and $\neq \mathrm{p}<0.05$ compared with normal controls $\left(\chi^{2}\right.$ analysis).

$\mathrm{D}$ and $\mathrm{C}=$ Dilatation and curettage

$26(90 \%)$ of 29 patients. In patients with chronic active hepatitis or alcoholic liver disease hysterectomy had been performed a mean of 13 years (range 1020 years) and $17 \cdot 8$ years (range 16-20 years), respectively, before the diagnosis of the liver disease.

The main clinical indication for hysterectomy in the patients with primary biliary cirrhosis was menorrhagia $(83 \%)$; this was similar for the control groups (table). Findings at hysterectomy were compatible with such symptoms. For patients with primary biliary cirrhosis these comprised fibroids $(51 \%)$, endometriosis $(21 \%)$, pseudomucinous cystadenoma (10\%), endometrial polyps (7\%), and carcinoma of the cervix $(3 \%)$. Patients in the control groups had similar findings. Of the 21 uteri removed from patients with primary biliary cirrhosis that were examined microscopically, endometrial hyperplasia was detected in five $(24 \%)$.

The percentage of patients with primary biliary cirrhosis who had previously undergone dilatation and curettage was significantly higher than that for the control subjects (table). Dilatation and curettage had been performed a mean of 13.2 years before the diagnosis of liver disease in 22 $(85 \%)$ patients with primary biliary cirrhosis, the clinical indication in most cases being menorrhagia or irregular menstrual bleeding (table). The age at menopause in the patients who had not undergone a hysterectomy was significantly lower in patients with primary biliary cirrhosis or alcoholic liver disease than in age matched normal subjects (table).

\section{Comment}

The significantly higher incidence of hysterectomy or dilatation and curettage, the indications in both instances being menorrhagia, in patients with primary biliary cirrhosis than in normal subjects and patients with other chronic liver diseases has not been reported previously. Coagulation abnormalities and myxoedema, both of which may occur in association with primary biliary cirrhosis, were excluded as possible causes of menorrhagia.

The underlying pathological abnormalities found in the specimens obtained at hysterectomy - namely, fibroids, polyps, endometrial hyperplasia, and endometriosis-are all believed to be caused by, or exacerbated by, high oestrogen states. ${ }^{1}$ In a recent study of postmenopausal women with chronic liver disease high free oestrogen concentrations and higher free oestrogen to androgen ratios were found than in age matched controls. ${ }^{2}$ Although the abnormalities were no greater in patients with primary biliary cirrhosis than in the other liver disease group (alcoholic cirrhosis), the functional disturbance in primary biliary cirrhosis may have been present for longer. The existence of a prolonged asymptomatic phase of primary biliary cirrhosis is now well documented, ${ }^{3}$ and it is possible that when the hysterectomies were carried out the disease was already present in an asymptomatic phase.

Dysfunctional uterine bleeding as a cause of the menorrhagia also needs to be considered. This occurs as a result of excessive proliferation of the endometrium caused by unopposed oestrogen action consequent on anovulatory cycles, ${ }^{4}$ and the latter are occasionally associated with follicular cyst formation of the ovaries. Interestingly, five of the 21 uteri examined and five of 14 curettings obtained showed endometrial hyperplasia, and in six patients follicular cysts of the ovary were noted at the time of hysterectomy.
A postmortem study of women with cirrhosis has found patho- $\overrightarrow{\vec{\omega}}$ logical evidence of hyperoestrogenism, and this lends support to $\stackrel{\circ}{\circ}$ the presence of an absolute or relative excess of oestrogen as the cause of the menorrhagia in primary biliary cirrhosis.

We are grateful to Mr John Studd for his advice.

\section{References}

1 Whitfield CR. Endometriosis. In: Dewhurst J, ed. Integrated obstetrics and gynaecology for 윽 postgraduates. London: Blackwell Scientific Publications, 1981:536-49.

2 Wilkinson M, Iqbal J, Johnson P, Williams R. Abnormal relationships between sex-steroids and SHBG in primary biliary cirrhosis. Gut 1983;24:A490.

3 Long RG, Scheuer PJ, Sherlock S. Presentation and course of asymptomatic primary biliary cirrhosis. Gastroenterology 1977;72:1204-7.

4 Studd J, Thom MH. Oestrogens and endometrial cancer. In: Studd J, ed. Progress in obstetrics and gynaecology. London: Churchill Livingstone, 1981:182-98. Barr R, Sommers S. Endocrine abnormalities accompanying hepatic cirrhosis and hepatoma. 7 Clin
Endocrinol 1957;17:1017-29.

Accepted 21 April 1986)

\section{YEARS AGO}

The East London Waterworks Company deserve at least some commiseration, for, as the results of an accident, they are now involved in a difficulty from which it will require all their energy and ingenuity to free themselves. Some years ago one of their filter-beds gave way, and "some eels of very minute size" found their way into the Company's mains. Since then these creatures have grown, and rapidly increased in numbers, and periodically, in the warmer months, they have manifested their presence in certain localities, despite all the efforts of the Company's staff to get rid of them. Occasionally a communication-pipe becomes blocked, and examination discloses a dead eel to be the cause. In several cases the water from the pipe has been noticed to be bad, and those who have drunk of it have suffered from more or less severe illness. The cause has been found to be a putrid eel. Quite recently a case of typhoid fever in the West Ham district has been investigated, and one of the causes alleged is the presence in the water of a dead eel. However this may be, it is not pleasant to have any doubts raised as to the purity and wholesomeness of the water from the household tap. The puzzling part of the whole matter is that eels are able to exist in the mains in spite of the enormous pressure of water, which varies from $30 \mathrm{lbs}$. to $100 \mathrm{lbs}$. to the square inch. And further, upon what do the creatures live, since the water is presumably pure? Is the water as free from organic impurity as it professes to be; or is there something in it which serves the eels for food, and which, apart from the eels, might of itself, under favouring circumstances, prove injurious to the drinkers of the water? There is one way by which the consumers of this water can protect themselves, and that is by boiling it before use. This course is habitually adopted by many prudent housekeepers in districts where eels are not known to exist, and we commend its adoption in the present case. It is a pity the process of boiling cannot be applied to the eels in the mains. They could scarcely be expected to resist that "pressure," and their dead bodies could no doubt then be finally flushed out. (British Medical Fournal 1886;ii:729.) 